sowing the microbial preparation Melanoriz at a rate of $1,5 \mathrm{l} / \mathrm{t}$ with a plant growth regulator Agrolight at a rate of 0,26 l/t followed by spraying of crops with Agrolight at a given background under normal conditions 1,0 l/ha, where the activity of catalase on the fifth and tenth days of studies increased to control by 7,8-7,9 $\mu$ mol of decomposed $\mathrm{H}_{2} \mathrm{O}_{2}$, peroxidase - 25,1-26,1 umol of oxidized guaiacol, polyphenol oxidase - 7,6-9,7 4 mol of oxidized ascorbic acid.

Key words: hulled oat, plant growth regulator, microbial preparation, catalase, peroxidase, polyphenol oxidase.

УДК: 633.11:631.53

DOI 10.31395/2415-8240-2020-96-1-23-52

\title{
THE INFLUENCE OF THE DURATION, THE METHOD OF SOWING AND THE REDUCTION RATES ON THE GROWTH AND PRODUCTIVITY OF WINTER WHEAT
}

S. POLTORETSKYI, Doctor of Agricultural Sciences

S. TRETIAKOVA, PhD of Agricultural Sciences

I. MOSTOVIAK, PhD of Agricultural Sciences

A. YATSENKO, Doctor of Agricultural Sciences

N. POLTORETSKA, PhD of Agricultural Sciences

A. BEREZOVSKYI, PhD of Agricultural Sciences

Uman National University of Horticulture

Наведено аналітичний огляд вітчизняних $i$ зарубіжних літературних джерел, щцодо впливу строку $i$ способу сівби на ріст, продуктивність, забур'яненість, ураження посівів пшениці озимої (Triticum aestivum L.) хворобами і шкідниками в різних трунтово-кліматичних умовах. В результаті проведеного аналізу встановлено, що науковиі й до нині не мають єдиної думки 
стосовно конкретних параметрів виконання цих агрозаходів. Проте, більшість 3 них зазначають, щуо в останні 10-15 років оптимальні строки сівби змістилися від оптимально ранніх до середніх $i$ оптимально пізніх 3 урахуванням конкретних трунтово-кліматичних умов регіону вирощування культури. Вибір строку сівби супроводжується змінами й стосовно інших елементів технології вирощування пшениці озимої - добору сортів стосовно групи стиглості, встановлення норми висіву й способу сівби. Неоднозначним є вплив цих агрозаходів на продуктивність посівів та якість сформованого врожаю.

Ключові слова: пшеничя озима, строк сівби, ріст, продуктивність, щільність агроченозі, ураженість, хворобами і шкідниками.

State of the problem. Humanity was dependent on wheat for many generations. It played a significant role in the Western Hemisphere for over 400 years [1]. Concerning the East, it is not possible to state with certainty a period of history when a human did not use this crop. Currently, T. aestivum L. and T. durum L. are the most widespread in terms of area and bulk yield among the wide species range of Triticum genus. Triticum aestivum L. is grown on the area of over 240 million hectares. No other cereals have such volumes. However, the average annual production rate of wheat grain is far behind the rate of increase in the human population. The growing imbalance is solved by the increase in wheat production, which in turn can be achieved by increasing the crop acreage and enlarging the yield level. The maximum yield of wheat can reach 20,0 t/ha in the experimental fields [2], whereas its average yield in the world was only $2,86 \mathrm{t} / \mathrm{ha}$ in 2006 , so this is not enough to meet the world's needs, and it is desirable to bring it up to $3,8 \mathrm{t} / \mathrm{ha}$ by 2025 .

Improving the species technology of growing is one of the main reserves for increasing the production of high quality grain of Triticum aestivum L. In particular, this concerns the optimization of the sowing time, sowing methods and seeding rates, which are effective agro-technical measures in realizing the productivity potential of the newest species. 
Material and methods. General scientific methods, in particular, such as: hypothesis, observation, analysis, synthesis, induction and deduction, abstraction and generalization were used during performing the study. Own observations and literary sources on the chosen sphere of the research were the material basis.

Results of the research. It is necessary to have a clear idea on the interaction of all factors that significantly affect the yield capacity in order to manage the processes of yield formation. The improvement of sowing structure is the main factor in the productivity increasing of winter wheat. It is determined by the density of the plant stand, which depends primarily on the sowing time, seeding rate, field germination of seeds and plant survival. Timely sowing is extremely important, and often crucial for good wintering and high productivity of winter crops [3].

Research showed that the optimal time now shifted 7-10 days later than it was 10-15 years ago, and it was between September 25 and October 10. The maximum differentiation of the species by the genetic potential of productivity was achieved during these sowing time. Thus, the yield of species of the last years of registration increased by $0,43-0,97 \mathrm{t} / \mathrm{ha}$, or by $7,4-8,2 \%$ in comparison with Albatros odeskyi under the same research conditions [4].

O. O. Kuleshov [5] presented the average optimal sowing time for winter wheat - September 8, which coincided with the oncoming of the average daily temperature of $15^{\circ} \mathrm{C}$, and was the temperature limit between summer and autumn.

Sowing time had a significant impact on plant growth and development, frost and winter resistance, plant survival, density of productive stems, yield and product quality according to the research by O. Demydov et all. [6]. Therefore, winter wheat plants effectively used their growth and development potential and produced the highest yield under the optimal sowing time. Similar findings were confirmed in other cereals, including spring crops [7]. Plant resistance to pests and diseases significantly depended on the sowing time according to the observations of F.X. Oury, C. Godin [8].

Sowing of winter wheat in August was accompanied by considerable damage of the sowings by Hessian fly and suffered from brown rust based on the data of 
I. V. Bondarenko [9]. In this regard, V. V. Bazalii [10] noted that the optimum sowing time shifted to the later one from September 1 to 15 - in Polissia, from September 5 to 20 - in the Forest-Steppe, from September 5 to 25 - in the Steppe and from September 25 to October 5 - in the Crimea.

Similar research results were also obtained by S. I. Popov [11]. Thus, winter wheat sowings were damaged by pests by $-62-63 \%$ after the sowing on 01.09 , by $36-51 \%$ after the sowing on 10.09 ; by $22-47 \%$ after the sowing on 20.09 and by $7-$ $11 \%$ after the sowing on 30.09. In addition, early sowing plants more suffered from diseases and the sowings were heavily weeded. The high temperature observed at the beginning of September contributed to the active flight of cicadas, cereal flies (Oscinella, Hessian, Phorbia securis, Chlorops taeniopus) and their laying eggs on the sowings and vegetative plants of winter wheat. Some flies (winter Opomyza and Opomyza germinationis) laid eggs on the ground near the sowings, wintered and damaged wheat sowings in spring.

Overwintering weeds in the plant stand of winter wheat was $56 \%$ after the sowing on September 1, and it was twice less after the sowing on September 20 according. In the spring, weeds grew faster during the tillering stage of winter wheat, taking some of the nutrients and moisture which resulted in a slowdown in the plant growth, decrease in agrocenosis and lowering of the yield.

Winter wheat should be sown in the second half of the optimal time for a specific region of the research to reduce the impact of pests and diseases on winter wheat plants, to ensure the best yield of winter crop according to a number of authors as N. Glukhova, M. Elnikov, N. Riabchun [12].

Studies conducted in Uman National University of Horticulture (southern part of the Right-Bank Forest Steppe) showed that shifting the optimum sowing time to a more later period did not significantly change the winter resistance level, whereas early sowing done on August 25 caused its sharp decrease in the species of Odeska 267, Ukrainka odeska and Krasunia odeska by $51 \%, 55 \%$ and $54 \%$ respectively [13].

The optimal sowing time for the preparation of plants for winter was one of the 
most effective measures, and too early and late time did not ensure successful preparation of plants for wintering [14]. Yu. F. Tereshchenko [15], V. Lykhochvor, S. Kostiuchko [16] considered that it was necessary 40th to 55th day with the sum of positive temperatures of $450-500$ and $510-550^{\circ} \mathrm{C}$, respectively, for normal growth and development of plants in the autumn period under the favourable conditions.

Reduction in winter resistance was also observed in the early sowing time according to V. V. Liashenko [17]. The highest grain yield (4,41 t/ha) was obtained after sowing on 09.09 and seeding rates of 4,5 million/ha of germinable seeds. The highest grain yield (4,04 t/ha) was received at a seeding rate of 5,5 million seeds per 1 ha at the more lately sowing time (25.09).

The studies of V. Lykhochvor, S. Kostiuchko [16] showed that frost training in winter cereals began with a multi-day influence of the temperatures slightly higher $0{ }^{\circ} \mathrm{C}$. During this phase, sugar and other protective substances accumulated in the protoplasm, the cells were dehydrated and the central vacuole broke down into much smaller ones. The protoplasm became ready for the next phase due to this, passing at constant light frosts from minus 3 to minus $5{ }^{\circ} \mathrm{C}$. Under these conditions, the ultrastructures and enzymes of the protoplasm were restructured so that the cells withstood the dehydration connected with the ice formation. Only after that the plants could enter the final phase of the frost training process, which made the protoplasm frost-resistant at continuous frost at least from minus 10 to minus $15^{\circ} \mathrm{C}$.

The slowing down of the ice formation in the tissues was caused by a decrease in the freezing point of the solutions. Cellular juice froze at the temperatures from minus 1 to minus $5{ }^{\circ} \mathrm{C}$, depending on the concentration of sugars in it. Cells united in tissues froze at lower temperatures than cellular juice. Besides, the water in the cells was capable of being overcooled, that was, it could be cooled below the freezing point without the simultaneous formation of ice. Reducing of the freezing point gave, although limited, but the only protection of the plants from frost during the vegetative period [17].

N. A. Bome [19] considered that the biological stability of winter wheat plants in spring-and-summer period, that was from the beginning of the vegetation 
restoration in spring and to full grain maturity was much lower compared to its autumn vegetation period. In addition, the stability depended on the precursor, sowing time, weather conditions and, to a certain extent, on the species characteristics. Sowing in the early and late time caused a decrease in plant survival in the spring-and-summer period.

The sowing time also affected to the duration of the vegetative period of plants of winter wheat. The duration of the sowing-seedling period in winter wheat of Myronivska 808 variety varied in the range of 9-16 days depending on the sowing time, 22-26 days in the seedling-tillering period in the experiments of V. N. Remeslo, I. I. Blokhin, F. F. Saiko [14] and other scientists.

This affected the plant tillering even during the late sowing (October 5), the plants tillered slightly in autumn. In autumn, they managed to form only one stem with a bush node that had a poorly developed secondary root system, so such sowings continued a slight tillering in spring. Then this phase lasted long enough $-30-40$ days if the sowing time was late.

V. V. Liashenko [17] noted that the plants of early sowing time developed a large vegetative mass during the termination of autumn vegetation, lost part of the leaves (a third of the vegetative mass died during this period), whereas only $2-5 \%$ in the plants sown in the optimal time.

The ability of tillering was the important feature of winter wheat. Winter resistance and crop productivity was connected with this process. The intensity of tillering depended on many factors. Thus, in the experiments of V. V. Lykhochvor [20], the tillering coefficient increased during the early sowing time $(1,6-3,1)$ and decreased - in the late one $(1,1-2,1)$. Increasing in tillering capacity contributed to excessive consumption of moisture and nutrients because the lateral stems, reducing the supply of the main stem with water and nutrients, did not compensate these losses. In addition, the main stems formed better grain by quality.

The number of plants with one and three stems decreased at a yield of 9,0-10,0 t/ha and virtually all agrocenosis was represented by two-stemmed plants according to the data of M. M. Korkhova [21]. Intra-species competition was reduced in the 
sowings with equally developed strong plants. It was also found that winter resistance of winter wheat significantly depended on the duration of the tillering period of the plants in autumn and on the intensity of this process, which was related to the soiland-climatic and agro-technical conditions of growing.

The highest tillering coefficient of winter wheat plants was observed in Myronivska variety $808(2,32-2,50)$, in Poliska $70-(2,24-2,38)$ at the sowing on September 10, while it decreased to 2,07-2,22 and 2,04-2,16, respectively, at the sowing on October 10 according to the reports of V. V. Lykhochvor [20] and M. Ya. Kyrpa [18].

Winter wheat had great tillering potential (up to 100 stems and more). Most current technologies reduced the ability of plants for tillering to a minimum, and the basis of some of them was mainly a single-stem type of the plant with no lateral stems. This could probably be explained by the yield of modern varieties, and the over-tillering did not contribute to this [16].

At present, there are opposing views on the ability of winter wheat for tillering and the impact of this phenomenon on the yield. Thus, the sowings with well-tillered and rooted plants were less likely to die from unfavourable wintering conditions in the studies of N. Glukhova, M. Elnikov, N. Riabchun [12]. However, at the same time, the authors noted that excessive growth of the vegetative mass of the plants in the autumn period was not always a reliable indicator of high frost and winter resistance.

In contrast, O. Kucherenko et all. [22] found that winter wheat plants were less frost resistant in the early sowing time compared to those formed during optimal and late sowing time. In their opinion, the plants did not have time to accumulate the required amount of sugars, which negatively affected the level of frost resistance at the end of autumn vegetation in the result of the growth and overgrowth. It was necessary to use varieties characterized by the high rates of stem formation and had time for tillering before winter beginning to prevent winter damage of the sowings in the case of unwilling delays with seeding.

V. Druziak, V. Druziak \& N. Ponomareva [23] found that winter wheat better 
overwintered and provided the highest yield capacity when the plants formed 2-4 stems by the entry into winter, had a sufficiently developed above-ground mass and root system and accumulated the required amount plastic substances. For this purpose, the sum of average daily temperatures during the period from the seeding to the termination of the autumn vegetation had to reach $500-580{ }^{\circ} \mathrm{C}$. In this case, the plants were better winterized and produced higher yield capacity under productive tillering - 1,5-2,6 stems depending on the variety. The weak-tillered plants and strongly-tillered were always more productive than the single-stem plants in inferiority to the productivity of medium-tillered plants, since they had a better developed root system and assimilation apparatus.

V. V. Morhun, Ye. V. Sanin, V. V. Shvartau [24] presented some contradictory data. Thus, their reports said that sowing in the optimal time, depending on a particular zone, provided large yields and promoted the formation of relatively good physical and technological qualities of the grain (increased the mass of 1000 and the grain nature, the content of crude gluten). However, early sowing caused a decrease in protein content and a deterioration in the baking quality of the grain, and, on the contrary, the gluten content in the grain was higher than optimal at the latter sowing time.

The gluten content in winter wheat grain of Poliska 70 variety was $29,0 \%$ when sowing on September 10 and 30,7\% during its sowing on October 10 according to the observations of V. M. Pochynok, D. A. Kirizii [25]. Protein content under these conditions was 11,6 and $12,9 \%$, respectively.

H. O. Priadkina's researches [26] found that the protein and crude gluten content of winter wheat increased in most cases depending on the sowing time with yield increasing. The period of protein accumulation in the grain changed with increasing the duration of the vegetation period. The content of nitrogenous substances in the grain increased under late sowing. Thus, changing the lighting conditions, temperature regime, etc. during the vegetation period caused the corresponding deep changes in the activity and nature of the enzymes, and, accordingly, in the general metabolism in the plant. 
In the EU countries, great attention was paid to differentiation of the growing technology of winter wheat depending on the sowing time. Thus, A. L. McKendry, B. E. McVetty, L. E. Evans [27] found that the seeding rate depended on the sowing time: 250-300 pieces of germinable seeds at $1 \mathrm{~m}^{2}$ were optimal in the early sowing time, 400 pieces in the late time and $450-500$ pieces in the very late time.

The seeding rate of winter wheat should be differentiated depending on the biological characteristics of the variety according to Y. Zhang, Q. Song, J. Yan et all. [28]. The more matured the variety (the lower plant mass), the greater the seeding rate should be, as they tillered less and they formed less productive stems per unit area under the same seeding rate with the late-matured varieties.

Numerous research findings by X. G. Zhu, S. P. Long, and D. R Ort [29] indicated that an increase in seeding rate was accompanied by a decrease in field germination of seeds. Similar results of researches were given also by V. V. Lykhochvor [20] who noted that not all seeds got to the groove bottom of a seeder created by disks at the increased rate of seeding. In doing so, the seeds fell into the less moist soil which degraded its germination. This was especially true for the conditions of insufficient moistening of the southern part of the Forest-Steppe and the Steppe.

Field germination increased from $71,6 \%$ to $76,3 \%$ under decreasing of the seeding rate from 5,5 to 3,0 million pieces/ha according to H. O. Priadkina, O. V. Zborivska, P. L. Ryzhykova [30]. But some authors [31] confirmed that field germination also increased under higher seeding rates.

The field germination decreased under the action of drought which led to a reduction in the growth of germinal roots, and subsequently was accompanied by a delay in the formation of the secondary root system [32].

Recommendations on the optimal tillering rate were quite varied. Thus, this ratio was at the level of 1,5 under the widespread norms of sowing and seeding method of wheat. It was important to have synchronous development of all plant stems in order to obtain $9,0-11,0 \mathrm{t} / \mathrm{ha}$ of grain, so the number of productive stems should be 1,6-2,0 on average [33]. Other researchers believed that this figure should be 2-3,1 [34]. 
The conditions of moisture and light intensity were also important. Root nutrition of the plants occurred with the help of water. Its lack led to yield failure, suppression, and sometimes plant death. However, water excess also affected negatively the growth and development of the crop [25]. Tillering was delayed under insufficient autumn moisture which adversely affected the growth, development and evenness of stem stand of the agrocenosis [20].

The light regime of winter wheat influenced not only on the development but also the growth processes, stems height, leaves number, length and width of the leaf blade, since only $15-20 \%$ of the sun's radiation entered the lower level of the wheat stem stand [16].

V. V. Lykhochvor [20] stated that a minimum light intensity of 1,8 thousand lux was required for the normal growth and development of winter wheat plants. Direct sunlight at noon gave 30-40 thousand lux. But the intensity of lighting decreased in the first part of the day and after noon. Insufficient light could weaken photosynthesis which negatively affected the yield capacity and caused a sharp increase of sterile flowers in cereals when combined with a high nitrogen background.

Changes in the light intensity were often connected with the changes in the temperature regime of soil and sowing. In turn, this directly affected the passage of microbiological processes in the soil, and thus its nutrient regime. Therefore, the issue on the light effect on the plants was important both theoretically and practically. The optimum light regime of sowing could be created by an appropriate seeding rate, sowing method, number of plants per row.

Restoration of spring vegetation was of great importance for increasing the productivity of winter crops. Winter wheat tillered and rooted more strongly, they developed a larger area of leaf surface, their photosynthetic potential increased in the early time of sowing. The early time of the vegetation restoration of winter wheat had a positive effect on the growth of the vegetative mass, the light in the lower tiers of the stem stand which was accompanied by the formation of strong lower internodes and increase the plants resistance to lodging. The late restoration of vegetation caused the formation of undersized plants, blindness in the stem stand and decrease in the 
crops productivity [35].

O. L. Ulich et all. [31] noted that it was necessary to increase the seeding rate on the high agricultural background, because there should be more plants per unit area for better nutrient supply. This idea was particularly prevalent at the beginning of the introduction of the intensive growing technology of winter wheat, one of which was the requirement to obtain 500-700 productive stems per $1 \mathrm{~m}^{2}$.

Wheat plants had time to form 2-3 lateral stems in the autumn vegetation period, and it was possible to form 1-2 more lateral stems in the spring period according to H. O. Priadkina, O. V. Zborivska, P. L. Ryzhykova [30].

There was no consensus on the benefits of having the plants with minimal tillering coefficient over multi-stem ones. Therefore, there were the concepts of sowings with low tillering coefficient $(1,2-1,4)$ and the concepts of sowings with the plants with several stems. In most cases it also depended on the water regime and the expected yield level. That is why the researchers [14] of the $60-80$ s of the last century rejected the concept of a single-stem plant in the agrocenosis of winter wheat when the yield level rarely exceeded 4,0 t/ha. A tuft consisting of the main and two or three lateral stems with a well-developed secondary root system should form from the seed. The tuft was made up of several productive stems that developed almost synchronously under such development. It was the healthiest and the most powerful type of a tuft - it was resistant to lodging, diseases, etc. However, under such conditions, it was important to prevent the formation of the stems of the second and subsequent layers.

H. O. Priadkina, O. V. Zborivska, P. L. Ryzhykova [30] considered that the first 4-5 stems were almost indistinguishable in both the size of the straw and the length of the spike and the number of spikes and grains in it under a large feeding area.

A considerable amount of experimental data confirmed the value of not only lateral productive stems. Thus, V. V. Lykhochvor [20] considered that the lateral stems, which did not even form grains and were temporary competitors in the struggle for nutrients, light and moisture, had a positive effect on yield. The assimilation apparatus increased by the help of such stems, which accumulated more 
plastic substances which later moved into spiky stems and increased their productivity.

This was confirmed by the fact that, according to V. G. Druzyak, V. V. Druzyak, N. V. Ponomareva [23], the productivity increased twice in the presence of one spineless unfertile stem of a single-spiked plant, and three or more times under three - five unproductive stems. Extra productive stems increased yields by $30-50 \%$. The grain yield in the thin sowings was dependent on $60-70 \%$ on the lateral stems. All this also depended on the conditions of vegetation - especially moistening and nutrition level of the plants.

Multi-stem plants had a better developed above-ground mass and root system, were more resistant to unfavourable growing conditions and were capable of producing greater productivity compared to the underdeveloped single-stem plants. However, the die-off of individual stems at the time of stem elongation in the highlytillering plants was not equivalent to the death of the entire light-tillering plant at the high density of the stem stand [35]. Therefore, scientists such as P. Gyuga, A. L. Demagante., G. M. Paulsen [36] and others considered that tillering had a positive effect on the yield of winter wheat. Although, this did not indicate the planned level of the yield. It should also be noted that the above sources of literature were 1947-1970 when a sufficient yield level was 3,0-3,5 t/ha.

The influence of the seeding rate $(3,0,6,0$ and 8,0 million germinating seeds per $1 \mathrm{ha}$ ) on the winter wheat productivity was studied at Uman National University of Horticulture [31]. Thus, it was found that the duration of nutrient supply to the grain was 33 days, respectively, depending on the seeding rate at 3,0 million germinable seeds per 1 ha, and 29 days at 8,0 million pieces/ha. The weight of 1000 grains was 42,8 and $44,6 \mathrm{~g}$, respectively,

The weight of the grain decreased by $14 \%$ starting from the second stem and the stems of the following layer were even less productive according to O. L. Romanenko, V. S. Rybka et all. [37]. Therefore, the authors concluded that it was advisable to create varieties with a low coefficient of tillering, that was, mostly single-stem ones. 
It was necessary to apply certain agrotechnical measures, in particular to increase the seeding rate in order to achieve the homogeneity of a productive stem stand in which there would be no competition between highly-tillering multi-stem and poorly developed single-stem plants according to the thought of V. D. Medynets, V. A. Sleptsov, M. M. Opara [38]. Increasing the coefficient of tillering of more than 1,5 required much more material costs, so it could not justify itself in the production conditions according to the supporters of single-stem type plants.

It should be noted that multy-stem plants in the sowings of the newest varieties of winter wheat were absent. This was due to the fact that a large initial density of the agrocenosis was formed in the result of the high seeding rates.

The seeding rates of winter wheat of each variety should be studied differentially, depending on the soil-and-climatic conditions, the precursor, the level of nutrition, agrotechnics, sowing time, taking into account the weather conditions of autumn and the water regime of the soil [20].

The research results of A. V. Cherenkov et all. [39] found that an increase in the sowing rate which directly caused plant thickening in the germination phase decreased plant survival both during the entire vegetation period and during separate interphase periods. However, the number of the productive stems was almost the same -831 and 841 pieces $/ \mathrm{m}^{2}$, respectively, under the seeding rates of 2,5 and 6,5 million pieces of seeds per 1 ha in the experiments of O. L. Romanenko, V. S. Rybka et all. [37].

V. V. Lykhochvor [20], O. L. Ulich [31] considered that it was advisable to increase the seeding rate by $20-25 \%$ under the unfavourable conditions, as this reduced the plants tillering. The density of the plants was unequally increased with raising the seeding rate, and the indicator of the conservation of wheat plants until harvest.

A detailed analysis of the dynamics of the plant density was performed by V. V. Lykhochvor [20] in different phases of their growth and development, namely the proportion of dead plants in the separate interphase periods suggested that the seeding rate should be changed depending on the sowing time. Thus, the number of 
plants died in the autumn period increased with the seeding rate, which was observed in the early and optimal sowing time for a growing zone.

Sowing time also played a decisive role in the reduction of stems under the influence of environmental factors during the summer vegetation and in the formation of the productive stem stand. The most intensive die-off of stems was observed in the variants of early sowing time (September 5-7) and especially in the second half of the vegetation based on the data of P. B. Barraclough, R. Lopez-Bellido, M. J. Hawkesford [40]. This was mainly due to the development and harmful effects of fungal and viral diseases and pests on the plants. Therefore, only $39 \%$ of the stems formed a productive spike from the common stem stand in the early sowing time. Stem reduction in the variants of the optimal (September 25-27) and late (October 10-15) sowing time had different intensities during the vegetation. There were lower indicators under the optimal sowing time, but in the end productive tillering was almost the same.

The number of varieties (Vdala, Pysanka, Skarbnytsia, Antonivka, Kosovytsia, Misia odeska, Blahodarka odeska, Sluzhnytsia odeska, Hoduvalnytsia odeska) were distinguished by a high level of realization of the general tillering in the productive one. Such varieties were able to withstand the high density of the productive stem stand (up to $820-900$ productive stems per $1 \mathrm{~m}^{2}$ ) and to form a sufficiently productive spike from the stems of the second and the following layers of tillering according to [30]. Concluded that many genetic and physiological systems of adaptation and productivity formation which determined the plants resistance to biotic and abiotic factors, the growth rate and development of the plants and was realized at a certain level were determined under the influence of different sowing time in winter wheat plants.

Emphasized that it was important to specify the duration of optimal and acceptable sowing time for each regionalized variety in each soil-and-climate zone, taking into account also the peculiarities of its predecessor, weather and phytosanitary conditions [41, 42].

Sowing methods played an important role in increasing crop yields. They also 
used spaced, single-grain, rowless and others methods in addition to the usual row method of sowing. Spaced sowing can be whole-rowless, supernarrow-row, row or broad-row, seed in a row spread in a line of 5-10 $\mathrm{cm}$ by width.

Spaced sowing gave the opportunity to optimize the feeding area in the ratio of $1: 3,1: 2$ and $1: 1$. The best results were provided by the seeders with anchor coulters and a row spacing of $7,5 \mathrm{~cm}$ according to V. V. Lykhochvor [20]. A. Kharub, S. Chander [43] came to these conclusions.

The effectiveness of various sowing methods at the former Mironivka Research Station began to be studied as early as 1914-1917. This issue has been repeatedly referred to because of the growth of new varieties. The establishment of the optimal sowing methods became especially relevant when growing winter wheat by resourcesaving technology and the introduction into the production of varieties of the intensive type [20].

It was possible to regulate the water, air, light and nutritional regime of sowing by changing the structure of agrobiocenosis using the sowing method. The feeding area depended on the sowing method. It would be optimal in case of full realization of the biological potential of winter wheat productivity. It was necessary to take into account varietal features, in particular the height of plants, the ability for tillering, the size of the leaf surface, etc. Until then, a regular row method with a row spacing of $15 \mathrm{~cm}$ was considered to be the most efficient method of sowing [41].

However, according to S. I. Popov [11], a narrow-row method of sowing increased the yield by one quintal compared to a regular row one. Spaced method of sowing was well if performed at a high technological level according to V. V. Lykhochvor [20]. However, it was still not widespread due to the lack of agricultural machines for its qualitative performing. In Canada, direct sowing machines (Flexi-Coil) provided a complete rowless method of sowing with a high evenness of seed placement [43].

The issue on architectonics of the stem stand was debatable, and still unresolved, to that day. Plants should be placed on the area in such a way that their mutual negative impact on each other was minimized. Intraspecific competition, the extent of 
which was most determined by the feeding area, was manifested in the competition for living space, which made it possible to absorb more nutrients and moisture and use maximum solar energy for the operation of the photosynthetic apparatus. Unsuccessful seed placement on the area reduced field germination, tillering coefficient, density of the productive stem stand, plant survival and in the final analysis - the yielding capacity of the sowings.

The sowing method and seeding rate had the greatest influence on the future architectonics of the stem stand at the very initial stages of growth and development. Even placement of seeds in a row and by depth was an important condition for increasing the productivity of the agrocenosis. Currently existing methods of sowing did not fully provide the basic agro-requirements - even placement of seeds in the area, in a row and by depth of covering up in the soil according to [12].

Unlike others [42] noted that the regular row method of sowing with a row spacing of $15 \mathrm{~cm}$ gave too close seed placement in the row; with this method the feeding area in the form of an elongated rectangle was very unfit for the effective work of root system. The higher the seeding rate, the denser the plants were placed in a row and the more the feeding area narrowed. It was believed that the critical distance between the seeds in a row was from 1,0 to $1,4 \mathrm{~cm}$.

However, the average distance between the plants in a row would be $1,2-1,3 \mathrm{~cm}$ which was less than critical or equal to it at $15 \mathrm{~cm}$ between the rows and the seeding rate of 5,0-6,0 million germinable seeds per 1 ha. As a result, the internodes of the basal zone were stretched, tillering was reduced, unproductive plants proned to lodging were formed. The distance between the plants should be approximately 2,6 $\mathrm{cm}$ to reduce these negative phenomena. Some seeds were closer to each other as a result of the uneven placement in the row during sowing [15].

Thus, the distance between the seeds under the regular row method of wheat sowing ranged from 0 to $6 \mathrm{~cm}$ according to [4]. The seeds during germination released toxic chemicals into the soil that negatively affected the germination energy and sprouting. The closer the seeds were to each other, the more their negative interaction. 
The results of the research by V. V. Lykhochvor [20] showed that the reduction of row spacing from 15 to $5 \mathrm{~cm}$ contributed to the increase of the field germination by $8-10$, and grain yield - by $4-6 \%$. According to other data [15] the reduction of row spacing increased the number of spikes by $5-15 \%$, the yield - by $8-10$, and the evenness of plants placement in the area - by 15-20\%. On average, narrowing the row spacing by $1 \mathrm{~cm}$ gave an increase in grain about $0,7-1,0 \%$ from 1 ha. Reducing the width of row spacing contributed to a more even placement of seeds in the area and less plant thickening in the row. A narrow-row and a cross method provided the best evenness among common methods of sowing in production. M. Sanchez-Garcia, F. Alvaro, A. Peremarti et all. [41] considered increasing of general evenness of row sowings as a result of reducing the width of row spacing as more effective compared to improving the accuracy of seed placement in rows despite the interaction between these two directions.

It should be noted that some authors denied the need for even placement of seeds. Thus, the evenness of seeding in rows practically did not worsen the condition of sowings according to A. V. Cherenkov [35]. Literature sources indicated that the use of the systems of accurate seeding for small-seed crops did not have a significant positive effect. Accurate seeding did not increase the evenness of plant placement due to the natural thinning of the sowings.

According to [42], the distance between seeds in a row increased to 2,2-2,5 cm under a narrow-row sowing (row spacing of 7,5 cm) with a seeding rate of 5,0-6,0 million pieces/ha. Further narrowing of the row spacing on the existing types of seeders was accompanied by soil clogging. Coulters placement in two or more rows would not solve the problem of seeders clogging. In addition, there was a problem of uneven coulters move of front and rear row. However, the optimal distance between the plants should be $3-4 \mathrm{~cm}$ to ensure the process of primary tillering.

Conclusions. It was established that scientists still do not have a consensus on the specific parameters of the implementation of these agro-measures in the result of the conducted analysis. However, most of them pointed out that, in the last 10-15 years, the optimal sowing time changed from optimally early to medium and 
optimally late time taking into account the specific soil-and-climatic conditions of the crop growing region. The choice of sowing time was accompanied by changes in other elements of the growing technology of winter wheat - selection of varieties in terms of maturity group, determining of seeding rate and sowing method. The impact of these agro-measures on the productivity of the sowings and the quality of the formed yield is ambiguous.

\section{Література}

1. Моррис Е. Р., Сирс Э. Р. Цитогенетика пшеницы и родственных форм. Пшеница и ее улучшение. М.: Колос, 1970, с. 33-102.

2. Curtis B. C. Wheat in the World. Plant Production and Protection. 2002. Series 30. P. 1-18.

3. Сайко В. Ф., Сокоренко Н. В., Дымкович Д. А. Операционная технология возделывания зерновых культур. К.: Урожай, 1990. 312 с.

4. Jaksomsak P., et all. (2017). Responses of grain zinc and nitrogen concentration to nitrogen fertilizer application in rice varieties with high-yielding low-grain zinc and low-yielding high grain zinc concentration. Plant and Soil. № 411. P. 101-109.

5. Кулешов О. О. Урожайність і якість зерна сортів озимої пшениці залежно від попередників і строків сівби у південно-східній частині степової зони. Бюл. Ін-ту зерн. госп-ва. Дніпропетровськ. 2008. № 33/34. С. 92-95.

6. Демидов О., Кочмарський В., Кавунець В., та ін. Строки сівби озимої пшениці: рекомендації та реалії. Пропозиція. 2016. № 10. С. 54-60.

7. Gorash, O., Klymyshena, R., Khomina, V., Vilchynska, L. (2020). Ecological and biological conformity of conditions of the brewing barley cultivation zone. Ukrainian Journal of Ecology. Vol. 10(1). P. 246-253.

8. Oury F.-X., Godin C. Yield and grain protein concentration in bread wheat: how to use the negative relationship between the two characters to identify favourable genotypes? Euphytica. 2007. № 157. P. 45-57.

9. Бондаренко I. В. Оцінка стійкості сортів пшениці озимої проти 
шкідників запасів зерна. Вісник Центру наукового забезпечення АПВ Харківської області. 2015. Вип. 18. С. 13-22.

10. Попов С., Авраменко С., Манько К. та ін. Вплив норм висіву на урожайність пшениці озимої. Агробізнес. 2013. Режим доступу: https://docplayer.net/63942813.

11. Пшениця м'яка озима Достаток. Миронівський інститут пшениці імені В. М. Ремесла. Режим доступу: http://www.mip.com.ua/page/85-pshenytsyam-yaka-ozyma-dostatok.

12. Глухова Н., Ельников М., Рябчун Н. Современная селекция озимой пшеницы. Зерно. 2007. № 1. С. 32-37.

13. Давидюк Г. В., Олійник К. М. Продуктивність і якість зерна пшениці озимої за різних технологій вирощування. Міжвідомчий тематичний науковий збірник “Землеробство”. 2011. Режим доступу: http://www.institutzerna.com/library/pryadko/t.pdf.

14. Ремесло В. Н., Блохин И. И., Сайко Ф. Ф. Агротехника и качество зерна озимой пшеницы в лесостепи Украины. Вестник с.-х. науки. 1976. № 4. C. $51-58$.

15. Терещенко Ю. Ф. Урожай і якість зерна високопродуктивних сортів озимої пшениці залежно від попередників і удобрення. Землеробство в умовах південного Лісостепу України. 1971. С. 23-28.

16. Лихочвор В., Костючко С. Продуктивність колоса озимої пшениці. Агробізнес. 2010. № 1. С. 14-16.

17. Ляшенко В. В., Маренич М. М. Вплив строків сівби на продуктивність посівів пшениці озимої. Вісник Полтавської держ. аграр. Академії. 2010. № 2. С. 46-50.

18. Кирпа, М. Я. Крупність та посівні якості насіння пшениці озимої. Селекйія і насінниитво. 2015. № 103. С. 179-187.

19. Боме Н. А., Боме А. Я., Тетянников Н. В. Полевая всхожесть семян и выживаемость растений ячменя как показатели адаптации к меняющимся условиям среды. Аграрный вестник Урала. 2015. № 4(134). С. 15-18. 
20. Лихочвор В. В. Структура врожаю озимої пшениці: Монографія. Львів: Українські технології, 1999. 200 с.

21. Корхова М. М. Продуктивність сортів пшениці м'якої озимої залежно від строків сівби та норм висіву в умовах Південного Степу України: дис. канд. с.-г. наук: 0.01.09. Херсон, 2015. 204 с.

22. Кучеренко О. М., Хоменко Л. О., Ковалишина Г. М. та ін. Вплив зміни клімату на особливості морфологічного аналізу при оцінці стану перезимівлі пшениці м’якої озимої. Селекція і насінництво. 2013. Вип. 103. C. $107-114$.

23. Друз'як В. Г., Друзьяк В. В., Пономарева Н. В. Про методику визначення тривалості стадії яровизації та строків сівби озимої пшениці. Селекиіл і насінниитво. 2008. Вип. 96. С. 80-88

24. Моргун В. В., Санін С. В., Швартау В. В. Клуб 100 центнерів. Сорти озимої пшениці Інституту фізіології рослин і генетики НАН України та система захисту компанії «Сингента». К.: Логос, 2015. 146 с.

25. Починок В. М., Кірізій Д. А. Продуктивність і якість зерна пшениці у зв'язку з особливостями розподілу азоту в рослині. Физиол. и биохимия культ. pacm. 2010. 42, № 5. С. 393-402.

26. Прядкіна Г. О. Фізіологічні основи підвищення продуктивності рослин озимої пшениці. К.: ТОВ «НВП Інтерсервіс», 2014. 192 с.

27. McKendry A. L., McVetty P. B. E., Evans L. E. Selection criteria for combining high grain yield and high grain protein concentration in bread wheat. Crop Sci. 1995. № 35. P. 1597-1602.

28. Zhang, Y., Song, Q. Yan, J., et all. Mineral element concentrations in grain of Chinese wheat cultivars. Euphytica. 2010. № 3. P. 303-313.

29. Zhu X. G., Long S. P., Ort D. R. Improving photosynthetic efficiency for greater yield. Annu. Rev. Plant. Biol. 2010. Vol. 61. P. 235-261.

30. Прядкіна Г. О., Зборівська О. В., Рижикова П. Л. Депонувальна здатність стебла сучасних сортів озимої пшениці за змінних умов довкілля як фізіологічний маркер їх продуктивності. Вісн. Украӥнського товариства 
генетиків і селекйіонерів. 2016. Вип 14. №2. С. 203-209.

31. Уліч О. Л., Максимчук Г. П., Цюк А. О., В’ялий С. О. Вплив строків сівби і сортів на ріст і розвиток та врожайність озимої пшениці. Науковий вісник НАУ. 2002. № 58. С. 81-86.

32. Рябченко М., Михальова К. Порівняння якості зерна сортів озимої м'якої пшениці, вирощеної в засушливі й дощові роки. Агроном. 2009. № 3. C. 33-36.

33. Пальчук Н. С. Продуктивність різних сортів пшениці озимої залежно від умов вирощування в Північному Степу України. Селекиія $i$ насінництво. 2014. Вип. 106. С. 155-162.

34. Caspy, I., Nelson, N. Structure of the plant photosystem. Biochemical Society Transactions. 2018. № 46. P. 285-294.

35. Черенков А. В., Солодушко М. М., Солодушко В. П. та ін. Вплив кліматичних змін на строки сівби пшениці озимої в умовах північного Степу. Агроном. 2014. № 3. 2014. С. 80-84.

36. Gyuga, P., Demagante A. L., Paulsen G. M.. Photosynthesis and growth of wheat under extreme nitrogen nutrition regimes during maturation. J. Plant Nutr. 2002. № 25(6). P. 1281-1290.

37. Романенко О. Л., Рибка В. О., Компанієць С. та ін. Агробіологічні та економічні питання вирощування сучасних сортів озимої пшениці в умовах південного Степу України. Бюл. Ін-ту с. г. степ. зони НААНУ. 2009. № 37.

38. Мединець В. Д., Слепцов В. А., Опара М. М. Ощадна технологія диференційованого догляду озимої пшениці. Полтава, 2004. 36 с.

39. Черенков А. В., Желязков О. І., Костриця І. В. Особливості росту та розвитку рослин озимої пшениці залежно від попередників, строків сівби та норм висіву насіння в умовах Присивашшя. Бюл. Інституту зерн. госn. Дніпропетровськ. 2008. № 33-34. С. 11-14.

40. Barraclough P. B., Lopez-Bellido R., Hawkesford M. J. Genotypic variation in the uptake, partitioning and remobilization of nitrogen during grainfilling in wheat. Field Crops Research. 2014. 156, pp. 242-148. 
41. Sanchez-Garcia M., Alvaro F., Peremarti A., et all. Changes in breadmaking quality attributes of bread wheat varieties cultivated in Spain during the 20th century. Eur. J. of Agronomy. 2015. № 63. P. 79-88.

42. Dromantiene R. Pranckietiene L. Sidlauskas G. Pranckietis V. The effect of fertilizers containing ami№ acids on winter wheat grain yield and technological properties. Zemdirbyste-Agriculture. 2009. Vol. 96(4). P. 97-109.

43. Kharub A., Chander S. Effect of nitrogen scheduling on wheat (Triticum aestivum) productivity and quality under alternate tillage practices. Indian Journal of Agricultural Sciences. 2010. Vol. 80 (1). P. 29-32.

44. Evans J. R. The relationship between electron transport components and photosynthetic capacity in pea leaves grown at different irradiances. Australian Journal of Plant Physiology. 1987. Vol. 14. P. 157-170.

\section{References}

1. Morris, E. R. (1970). Cytogenetics of wheat and related forms. Wheat and its improvement. Moscow, pp. 33-102. (in Ukrainian).

2. Curtis, B. C. (2002) Wheat in the World. In: Curtis, B. C., Rajaram, S. and Macpherson, H. G., Eds., Bread Wheat Improvement and Production, Plant Production and Protection. Series 30, FAO, Roma, pp. 1-18. (in English).

3. Saiko, V. F. (1986). Agrotechnical foundations of an intensive technology for the cultivation of winter wheat: abstract of the dissertation of Doctor of Agricultural Sciences: 01.06.09 crop production. Kharkov, pp. 36 (in Russian).

4. Jaksomsak, P., et all. (2017). Responses of grain zinc and nitrogen concentration to nitrogen fertilizer application in rice varieties with high-yielding low-grain zinc and low-yielding high grain zinc concentration. Plant and Soil, no. 411, pp. 101-109 (in English).

5. Kuleshov, O. O. (2008). Yield and quality of winter wheat grain depending on its predecessors and sowing time in the southeastern part of the steppe zone. Bulletin of the Grain Institute, no. 33-34, pp. 92-95. (in Ukrainian)

6. Demydov, O., et all. (2016). Winter wheat sowing time: 
recommendations and realities. PropozitsIya, no. 10, pp. 54-60 (in Ukrainian).

7. Gorash, O., Klymyshena, R., Khomina, V., Vilchynska, L. (2020). Ecological and biological conformity of conditions of the brewing barley cultivation zone. Ukrainian Journal of Ecology, 10(1), pp. 246-253 (in English).

8. Oury, F.-X., Godin, C. (2007). Yield and grain protein concentration in bread wheat: how to use the negative relationship between the two characters to identify favourable genotypes? Euphytica, no. 157, pp. 45-57 (in English).

9. Bondarenko, I. V. (2015). Estimation of resistance of winter wheat varieties against pests of grain reserves. Bulletin of the Center for Scientific Support of the APV of Kharkiv region, no. 18, pp. 13-22 (in Ukrainian).

10. Bazalii, V. V., et all. (2011). Hard winter wheat productivity depending on moisture conditions and mineral nutrition background in irrigation conditions of southern Ukraine. Taurian Scientific Herald, no. 77, pp. 12-20 (in Ukrainian).

11. Popov, S. I., et all. (2013). Characteristics and adaptive potential of universal winter varieties of winter wheat. Handbook of the Ukrainian farmer, vol. 1, pp. 288-290 (in Ukrainian).

12. Glukhova, N., Elnikov, M., Riabchun, N. (2007). Modern selection of winter wheat. Zerno, no. 1, pp. 32-37 (in Russian).

13. Davydiuk, H. V., Oliinyk, K. M. (2011). Productivity and quality of winter wheat grain with different growing technologies. Agriculture: Interagency thematic scientific collection, no. 83, pp. 72-77. (in Ukrainian).

14. Remeslo, V. N., Blokhin, I. I. Saiko, F. F. (1976). Agrotechnics and quality of winter wheat grain in the Forest-Steppe of Ukraine. Newspaper agricultural sciences, no. 4, pp. 51-58 (in Russian).

15. Tereshchenko, Yu. F. (1971). Yield and grain quality of high-yielding winter wheat varieties depending on precursors and fertilizers. Agriculture in the Southern Forest-Steppe of Ukraine, pp. 23-28 (in Ukrainian).

16. Lykhochvor, V., Kostiuchko S. (2010). Winter wheat ear productivity. Agribusiness, pp. 14-16. (in Ukrainian).

17. Liashenko, V. V. (2010). Influence of sowing periods on productivity of 
winter wheat crops. Bulletin of the Poltava State. agrarian of the Academy, no. 2, pp. 46-50_(in Ukrainian).

18. Kyrpa, M. Ya. (2015). Size and sowing qualities of winter wheat seeds. Breeding and seed production, no. 103, pp. 179-187 (in Ukrainian).

19. Bome, N. A. (2015). Field germination of seeds and the survival of barley plants as indicators of adaptation to changing environmental conditions. Agrarian Bulletin of the Urals, no. 04(134), pp. 15-18 (in Russian).

20. Lykhochvor, V. V. (1999). Structure of winter wheat crop: Monograph. Lviv: Ukrainian Technologies, 200 p. (in Ukrainian).

21. Korkhova, M. M. (2015). Productivity of wheat varieties of mild winter depending on sowing time and sowing rates in the Southern Steppe of Ukraine: aref. dis. Cand. agricultural Sciences: 0.01.09. Kherson. 20 p. (in Ukrainian).

22. Kucherenko, O., Khomenko, L., Kovalyshyna, H., \& Kochmarskyi, V. (2015). Impact of climate change on the features of morphological analysis in the evaluation of winter winter wheat. Breeding and seed production, no. 103, pp. 107114 (in Ukrainian).

23. Druzyak, V. G., Druzyak, V. V., Ponomareva, N. V. (2008). About the method of determining the duration of the yarovization stage and the sowing time of winter wheat. Breeding and seed production, no. 96, pp. 80-88 (in Ukrainian).

24. Morhun, V. V., Sanin, Ye. V., Shvartau, V. V. (2015). 100 Quarter Club. Winter wheat varieties of the Institute of Plant Physiology and Genetics of the NAS of Ukraine and the system of protection of the company "Singenta". Kiiv, 146 p. (in Ukrainian).

25. Pochynok, V. M., Kirizii, D. A. (2010). Wheat grain productivity and quality due to nitrogen distribution in the plant. Physiol. and the biochemistry of the cult. growth, no. 5, pp. 393-402 (in Ukrainian).

26. Priadkina, H. O. (2014). Physiological bases of increase of productivity of plants of winter wheat. Kiiv, 192 p. (in Ukrainian).

27. McKendry, A. L., McVetty, P. B. E., Evans, L. E. (1995). Selection criteria for combining high grain yield and high grain protein concentration in bread 
wheat. Crop Sci., no. 35, pp. 1597-1602 (in English).

28. Zhang, Y., Song, Q. Yan, J., et all. (2010). Mineral element concentrations in grain of Chinese wheat cultivars. Euphytica, vol. 174 (3), pp. 303313 (in English).

29. Zhu, X. G., Long, S. P., Ort, D. R. (2010). Improving photosynthetic efficiency for greater yield. Annu. Rev. Plant. Biol., vol. 61, pp. 235-261 (in English).

30. Priadkina, H. O., Zborivska, O. V., Ryzhykova, P. L. (2016). Depositing capacity of stems of modern winter wheat varieties under changing environmental conditions as a physiological marker of their productivity. Bulletin of the Ukrainian Society of Genetics and Breeders, vol. 14, no. 2, pp. 203-209 (in Ukrainian).

31. Ulich, O. L. et all. (2002). Influence of sowing dates and varieties on growth and development and yield of winter wheat. Scientific Bulletin of NAU, no. 58, pp. 81-86 (in Ukrainian).

32. Riabchenko, M. et all. (2009). Comparison of grain quality of winter soft wheat varieties grown in dry and rainy years. Agronomist, no. 3, pp. 33-36. (in Ukrainian).

33. Palchuk, N. (2014). Productivity of different winter wheat varieties depending on growing conditions in the northern steppe of Ukraine. Breeding and seed production, no. 106, pp. 155-162 (in Ukrainian).

34. Caspy, I., Nelson, N. (2018). Structure of the plant photosystem. Biochemical Society Transactions, no. 46, pp. 285-294 (in English).

35. Cherenkov, A. V. et all. (2014). The influence of climate change on the sowing time of winter wheat in the northern steppe. Agronomist, no. 3, pp. 80-84 (in Ukrainian).

36. Gyuga, P., Demagante, A. L., Paulsen, G. M. (2002). Photosynthesis and growth of wheat under extreme nitrogen nutrition regimes during maturation. J. Plant Nutr., vol. 25, no. 6, pp. 1281-1290 (in English).

37. Romanenko, O. L., Rybka, V. S. et all. (2009). Seeding rates: Agrobiological and economic issues of cultivation of modern winter wheat varieties in the southern steppe of Ukraine. Bulletin of the Institute of Agriculture of the Steppe 
Zone of NAAS, no. 37 (in Ukrainian).

38. Medynets, V. D., Sleptsov, V. A., Opara, M. M. (2004). Savings technology of differentiated care of winter wheat. Poltava, 36 p. (in Ukrainian).

39. Cherenkov, A. V. et all. (2008). Peculiarities of growth and development of winter wheat plants depending on their precursors, sowing time and seed sowing rates in Prisivashia. Bulletin of the Grain Institute, no. 33-34. pp. 11-14.

40. Barraclough, P. B., Lopez-Bellido, R., Hawkesford, M. J. (2014). Genotypic variation in the uptake, partitioning and remobilization of nitrogen during grain-filling in wheat. Field Crops Research, no. 156, pp. 242-148 (in English).

41. Sanchez-Garcia, M., Alvaro, F., Peremarti, A., et all. (2015). Changes in bread-making quality attributes of bread wheat varieties cultivated in Spain during the 20th century. Eur. J. of Agronomy, no. 63, pp. 79-88. (in English).

42. Dromantiene, R. Pranckietiene, L. Sidlauskas, G. Pranckietis V. (2009). The effect of fertilizers containing ami№ acids on winter wheat grain yield and technological properties. Zemdirbyste-Agriculture, vol. 96, no. 4, pp. 97-109 (in English).

43. Kharub, A., Chander, S. (2010). Effect of nitrogen scheduling on wheat (Triticum aestivum) productivity and quality under alternate tillage practices. Indian Journal of Agricultural Sciences, vol. 80, no. 1, pp. 29-32 (in English).

44. Evans, J. R. (1987). The relationship between electron transport components and photosynthetic capacity in pea leaves grown at different irradiances. Australian Journal of Plant Physiology, no. 14, pp. 157-170 (in English).

\section{Аннотация}

Полторецкий С., Третьякова С., Мостовьяк И., Яценко А., Полторецкая Н., Березовский $А$.

Влияние срока, способа сева и нормы высева на рост и продуктивность пшеницы озимой

Постановка проблемы. На протяжении многих поколений существования 
человечества зависело от пшеницы. В Западном полушарии она имеет огромное значение уже более 400 лет. В Восточном - с достоверностью невозможно указать период истории, когда бы человек не использовала эту культуру. Сейчас, среди большого многообразия видов рода Triticum наиболее распространенными как по площуади, так и по валовыми сборам являются T. aestivum L., и T. durum L. Пшеницуа мягкая выращчивается на площуади более 240 млн га. Таких площуадей более не имеет ни одна зерновая культура в мире. Однако среднегодовые темпь производства зерна пиеницы сильно отстают от скорости увеличения человеческой популяцฺии. Растущий дисбаланс решается увеличением прочзводства пиеницы, которое, в свою очередь, можно достичь за счет увеличения посевных площуадей и повыщения уровня урожайности.

На опьттных полях максимальная урожайность пшеницьь может достигать 20,0 m/га, тогда как ее средняя урожайность в мире в 2006 году составила лишь 2,86 m/2а. Для удовлетворения мировых потребностей этого недостаточно, и на период до 2025 года этот показатель желательно довести до уровня $3,8 \mathrm{~m} / 2 \mathrm{a}$. Одним и из основных резервов увеличения производства высококачественного зерна пшеницы мягкой озимой является совершенствование сортовой технологии выращчивания. В частности, это касается оптимизация сроков, способов посева и норм высева, которые являются эффективны агротехническими мероприятиями в реализации потенцииала продуктивности новых сортов.

Методика исследований. Использовали общенаучные методы,, в частности: гипотеза, наблюдение, анализ, синтез, индукция и дедукция, абстрагирование и обобщение. Базой проведенного исследования были собственные наблюдения и литературные источники по выбранной теме.

Результаты исследований. Приведен аналитический обзор отечественных и зарубежных литературных источников, о влиянии срока и способа посева на рост, урожайность, засоренность, поражение посевов пшенищы озимой болезнями и вредителями в различных почвенно- 
климатических условиях.

Выводы. Установлено, что ученые и в настоящее время не имеют единого мнения относительно конкретных параметров выполнения этих агроприемов. Однако, большинство из них отмечают, что в последние 10-15 лет оптимальные сроки сева сместились от оптимально ранних до средних $и$ оптимально поздних с учетом конкретных почвенно-климатических условий региона выращцивания культуры. Выбор срока сева сопровождается изменениями и в отношении других элементов технологии выращцивания пшенищь озимой - подбора сортов относительно группь спелости, установление нормы высева и способа сева. Неоднозначным есть влияние этих агроприемов на продуктивность посевов и качество сформированного урожая пшеницьь.

Ключевые слова: пиеница озимая, срок сева, рост, урожайность, плотность агроченоза, пораженность болезнями и вредителями.

\section{Annotation}

\section{Poltoretskyi S., Tretiakova S., Mostoviak I., Yatsenko A.,} Poltoretska N., Berezovskyi A.

The influence of the duration, the method of sowing and the reduction rates on the growth and productivity of winter wheat

Introduction. Humanity was dependent on wheat for many generations. It played a significant role in the Western Hemisphere for over 400 years. Concerning the East, it is not possible to state with certainty a period of history when a human did not use this crop.

Currently, T. aestivum L. and T. durum L. are the most widespread in terms of area and bulk yield among the wide species range of Triticum genus. Triticum aestivum L. is grown on the area of over 240 million hectares. No other cereals have such volumes. However, the average annual production rate of wheat grain is far behind the rate of increase in the human population. The growing imbalance is 
solved by the increase in wheat production, which in turn can be achieved by increasing the crop acreage and enlarging the yield level.

The maximum yield of wheat can reach 20,0 t/ha in the experimental fields, whereas its average yield in the world was only 2,86 t/ha in 2006, so this is not enough to meet the world's needs, and it is desirable to bring it up to 3,8 t/ha by 2025. Improving the species technology of growing is one of the main reserves for increasing the production of high quality grain of Triticum aestivum L. In particular, this concerns the optimization of the sowing time, sowing methods and seeding rates, which are effective agro-technical measures in realizing the productivity potential of the newest species.

Material and methods. General scientific methods, in particular, such as: hypothesis, observation, analysis, synthesis, induction and deduction, abstraction and generalization were used during performing the study. Own observations and literary sources on the chosen sphere of the research were the material basis.

Results of the research. The analytical review of domestic and foreign literature sources on the impact of term and method of sowing on growth, productivity, weediness, infestation of winter wheat (Triticum aestivum L.) by diseases and pests in different soil-and-climatic conditions was presented. It was established that scientists still do not have a consensus on the specific parameters of the implementation of these agro-measures in the result of the conducted analysis.

Conclusions. It was established that scientists still do not have a consensus on the specific parameters of the implementation of these agro-measures in the result of the conducted analysis. However, most of them pointed out that, in the last 10-15 years, the optimal sowing time changed from optimally early to medium and optimally late time taking into account the specific soil-and-climatic conditions of the crop growing region. The choice of sowing time was accompanied by changes in other elements of the growing technology of winter wheat - selection of varieties in terms of maturity group, determining of seeding rate and sowing method. The impact of these agro-measures on the productivity of the sowings and the quality of the formed yield is ambiguous. 
Keywords: winter wheat, sowing time, growth, productivity, agrocenosis density, infestation by diseases and pests.

УДК664.743:633.11:641.53:683.958

DOI 10.31395/2415-8240-2020-96-1-52-71

\section{ВИХІД КРУПИ ПЛЮЩЕНОЇ ІЗ ПШЕНИЦІ ПОЛБИ ЗАЛЕЖНО ВІД ТРИВАЛОСТІ ОПРОМІНЕННЯ ЕМП НВЧ І ВОДОТЕПЛОВОГО ОБРОБЛЕННЯ}

Н. М. ОСОКІНА, доктор сільськогосподарських наук

В. В. ЛЮБИЧ, доктор сільськогосподарських наук

В. В. НОВІКОВ, кандидат технічних наук

І. А. ЛЕЩЕНКО, аспірант

Уманський національний університет садівництва

Визначено вплив тривалості опромінення електромагнітним полем надвисокої частоти і проведення водотеплового оброблення під час плющення лущеного зерна пшениці полби (сорт Голіковська). Експериментальними дослідженнями встановлено, щуо при застосуванні изілої крупи № 1 вихід крупи плющеної вищуого сорту був у 1,7-2 раза менший порівняно з нелущеним зерном. Проведення зволожування має незначний вплив на вихід крупи плющеноӥ. Оптимальним періодом для виробнищтва крупи плющеенӧ вищуого сорту $\epsilon$ опромінення ЕМП НВЧ упродовж 80-100 с, зволоженого на 0,5-1,0 \% зерна.

Ключові слова: пшеницяя полба, цүіла крупа, зерно, плющееня, мікрохвильова niч.

Постановка проблеми. Нині збільшується зацікавленість щодо використання електромагнітного поля надвисокої частоти (ЕМП НВЧ/НВЧ- 